\title{
Transnational struggle for workers' rights and missing domestic links: the case of Japanese activists' involvement in the Toyota Philippines dispute
}

\author{
Katarzyna Gajewska, independent scholar, France
}

\begin{abstract}
ABSRACT
The case of Japanese activists' protest against Toyota's abuses in the Philippines will be analyzed to illustrate the potential for and obstacles to enforcing worker rights, such as the freedom of association in Japanese multinationals. The mainstream trade unions chose not to engage in the defense of workers' rights. The case reveals the presence of a network of labor movement organizations and groups, which can be mobilized at the local level. The background of members of the support group formed in Japan will be used as an example to understand the context of resistance-building against corporate abuses in Japan. This resistance building effort is rooted in the divisions in the Japanese labor movement that took place in the 1970s and new social movements.
\end{abstract}

\section{KEYWORDS}

Japan, labor movement, multinationals (MNCs), the Philippines, worker rights.

Some scholars optimistically view the formation of social movements as a force with the potential to resist the abuses of transnational companies (Beneria, 1995; Gajewska 2009; Munck, 2004; Waterman, 1998). The anti-corporate movement's demands and tactics can be conceptualized as a transformation or extension of citizenship norms to the international level: 'it functions to regenerate, at the international level, a public sphere' (Crossley, 2003: 289). While traditional centralized trade union organizations have lost their strength, networked actions show some promise of an effective pursuit of labor interests (cp. Heckscher and Carré, 2006; Levesque and Murray, 2002). Labor movements in core countries have resources and institutional opportunities to curb the behaviour of multinational companies by enforcing regulation in the country where their headquarters are based (Flynn and O'Brien, 2010). Departing from the proposal of Flynn and O'Brien (2010) to defend workers' rights by targeting core countries, home to many multinationals, I will examine the limitations of this approach in East and Southeast Asia based on the example of Japanese activism against Toyota's abuses in the Philippines. The affiliating of a foreign trade union with a trade union in the country where the multinational is based in order to represent foreign workers in the court, despite its innovative nature, failed in the Toyota case. 
Japan has played a crucial role in economic integration due to the expansionist strategy of Japanese MNCs (Suzuki, 2010). The Japanese labor movement is the strongest in the region in terms of available resources and influence on international trade union structures (cp. Ranald, 1999), therefore it is relevant to the development of resistance in Asia. The stances taken by labor unions in core countries play a crucial role in the dynamics of the world system (cp. Kwon et al., 2008). The character of social forces in Japan appears to undermine the emergence of movements and mobilization to defend Toyota workers' rights in Asia. The majority of labor movements in Japan are conciliatory and enterprise unions are close to the management. Opposition forces within the labor movement have been continuously weakened, and the close relation between labor and management has been cultivated for decades (Benson and Zhu, 2008; Gordon, 1998; Jeong and Aguilera, 2008; Kawanishi, 1992; Suzuki, 2003; Suzuki unpublished). Furthermore, civil society has been depoliticized and co-opted by the state (Avenell, 2009; Hirata, 2004; Pekkanen, 2003). On the other hand, one may argue that the network of movement groups that emerge outside statedefined civil society can have an influence despite its small size (cp. Steinhoff, 2008). Japanese activism and mobilization as seen in the Toyota case will shed more light on the anti-corporate social movement in Japan and its capacities.

The Toyota Philippines dispute has been analyzed and described in great detail in other publications (Tono, 2006; Wad and Tackney, 2009). The aim of this case study is to highlight one aspect that complements other factors rather than providing an encompassing explanation of the failure to defend workers' rights. Wad and Tackney (2009) analyze a broader set of factors, such as the mobilization of Japanese employers and the collusion of authorities with foreign companies in the Philippines. Their analysis benefits from a comparative approach, contrasting the Toyota dispute with workers' success in a Malaysian subsidiary of a Danish multinational, which illustrates the differences between domestic elites in each host country as well as the differing strength of labor forces involved in each home country campaign. The authors were inspired by Union Strategic Corporate Analysis (USCA) (Bronfenbrenner, 2007; Juravich, 2007) and the Comparative Employment Ecology Models (CEEM) (Tackney, 2000, 2001, 2002). I agree with their argument that the entire environment and related set of actors needs to be taken into account. I have chosen to engage in a more in-depth exploration of one of the factors, which is consistent with their perspective.

By focusing on an anti-corporate campaign organized by Japanese labor activists, I will shed light on labor forces present in Japan, which can be used as a basis for assessing the capacities to build resistance to Japanese multinationals' abuses abroad. So far, the transnational campaign has not yet succeeded in forcing the company to recognize the democratically elected trade union. The pressure on Japanese management in Japan has not yet had any effect despite the fact that Toyota's headquarters in Japan has the power to order local management in the Philippines to obey regulations but has chosen not to despite pressure on management in Japan (cp. Tono, 2006; Wad and Tackney, 2009). However, on a more optimistic note, this conflict fostered mobilization and transnational network building, which are preconditions for applying transnational tactics against a multinational company in its base country. I will analyze the formation of the Japanese support group to defend Filipino workers within the broader context of the labor movement in Japan, which is divided into mainstream and oppositional groups. This division has a long history and I will trace the development of internationalist groups relevant to the development of the network against Toyota. First, I will review the literature on the divisions in the labor movement and its impact on labor internationalism. 


\section{Division within domestic labor movements and internationalism}

Western trade unions have an interest in protecting the rights of workers since this in turn protects Western workers from the threat of competition with cheaper labor in other countries (cp. Flynn and O'Brien, 2010). For instance, the activists from core countries present at the World Social Forum were just as radical as the workers from periphery countries (Kwon et al., 2008). However, the selection bias of such a study needs to be taken into account. In Japan, national labor union organizations recognize the necessity of international strategies (Gajewska, 2013) but this orientation does not automatically translate to enterprise level tactics. Trade unions in the country in which a multinational company is based tend to identify with management (cp. Greer and Hauptmeier, 2008). The corporate and state policy has promoted cooperative orientation of the trade unions. ${ }^{1}$ In the 1970s, mainstream Japanese trade unions started to promulgate the idea that workers should cooperate with management in order to strengthen the company's competitiveness, since, they claimed, this was in the interest of all concerned, both the workers and the management identify workers' interests with the competitiveness of their employers. This is related to structural factors, such as an economic crisis and the 'white-collarization' of production in Japan, accompanied by the creation of a dual labor market (Carlile, 1994). In their international engagement with trade unions in developing countries, mainstream Japanese trade unions actively cultivate corporate identity with Japanese employers abroad (Williamson, 1994, but see Shimizu et al., 1998). In the event of an abuse committed by a Japanese multinational abroad, this protectionist attitude would discourage trade unions from cooperating or reacting, as this could damage relations with management and reduce profit from overseas subsidiaries of a company.

The literature mentions the occurrences of ideological divisions within national trade union movements, which are mirrored in their international tactics. At the plant level, a dominant conservative union may be opposed by more radical groups, which prefer an internationalist strategy (Anner, 2003). For example, German IG Metall and its works councillors were criticized by a more radical part of the workforce. Grassroots movements preferred a more internationalist and less concession-oriented tactics (Rehder, 2006). This implies that the organizational structure and ideological division of labor movements must be considered when assessing the potential for defending workers' rights transnationally.

In Japan, the Japan Trade Union Confederation (Nihon Rodo Kumiai So Rengokai), commonly called Rengo, unites most of the unions. Two other trade union confederations with a more radical ideological profile, Zenroren and Zenrokyo, are critical of Rengo. The former is informally linked with the Communist Party. While the popular image of the Japanese trade union movement is that of an enterprise-based union close to management, this is not the only type of labor movement organisation. There are also occupational and geographically based trade unions. Ideological pluralism is present at the enterprise level (cp. Urano and Stewart, 2009). Union schisms at the enterprise level have been widespread since the post-war period. Using case studies, Kawanishi illustrates how management achieved conciliatory relations with enterprise trade unions by promoting leaders from the management-friendly union and giving its members preferential treatment over those of other unions. Furthermore, these trade unions helped to marginalize oppositional trade unions. In the 1970s, two types of unions gained relevance at the enterprise level: left-wing minority unions (saha shosuha kumiai) and conservative enterprise unions. Another type of union that emerged, 'the new-type union' (shingata kumiai), represented marginalized workers such as women, disabled, or part-time workers (Kawanishi, 1992; also Stewart, 2006). Another typology 
of unions at the enterprise level is elaborated by Benson (1996), who distinguishes between company, enterprise, oligarchic, and independent unions according to their relations with management and involvement of the workforce in decision making. Independent unions democratic and distant from management - may be expected to oppose company abuses. The Toyota case will help to describe the composition of the Japanese labor movement and its implications for labor internationalism. In order to analyze prospects for defending workers' rights in developing countries, one must consider the relations between different groups which could unite against a multinational.

\section{Research design and methodological issues}

The case of resistance to Toyota abuses in the Philippines exemplifies corporate globalization dynamics: multinational companies are able to disobey labor rights in developing countries because of a weak labor movement there and low law enforcement capacity. This case study illustrates the strength of the anti-corporate network and the available tactics for resistance. Therefore, the campaign against Toyota can shed light on the conditions needed to effectively resist corporate globalization and, consequently, revitalize labor movements. The Toyota case illustrates the potentials and limits of the Japanese anti-corporate movement. One should note that there are also other groups active against the abuses committed by Japanese companies, ${ }^{2}$ not included in this case study.

Studying anti-corporate resistance involves certain methodological difficulties. Crossley (2002) points out that the anti-corporate global movement consists of various actors including organizations, informal groups, journalists, consumers and sympathizers. The anti-globalization movement is organized as a mobilizable network, rather than a hierarchic organization because the movement rejects delegation (Funke, 2008; Juris, 2008; McDonald, 2002). Similarly, and even more so, Japanese left-wing groups prefer to remain informal networks and 'invisible movements.' Their structure and organization is shaped by their aim of being independent of state influence. The groups form a network and cooperate with trade unions, Christian organizations and international counterparts. This network mobilizes occasionally to defend issues of common concern (Steinhoff, 2008). The lack of formal organizational structure makes it difficult for researchers to portray the movement in a representative way. Chan (2008) provides the most representative documentation of the anti-globalization forces in Japan. The case study method allows observing the mobilization potential within a loose network of groups and activists.

Although the Toyota case research focused on the 2000s, in order to understand these mobilizations against corporate abuses, one needs to go back to the 1970s. This paper will contextualize the Japanese social movement groups that mobilized against Toyota abuses within the broader development of social movements in Japan, tracing the domestic and international factors that influenced both phenomena. Interviewees were chosen according to their position within organizations and their long history of political activism, which make them experts on the social movements involved in alterglobalization politics in Japan. Two interviewees were involved in the Support Group for the Toyota Motors Philippines Corporation's Workers Association (TMPCWA) (hereafter referred to as the Support Group). Altogether, nine in-depth interviews on Japanese labor internationalism were conducted between January and May 2010 in Tokyo by a Japanese native speaker (who has expertise in Japanese trade unions and works as a translator) and translated into English. Written sources were also incorporated into the analysis. 


\section{Toyota company abuses and the main enterprise union}

The Toyota trade union was established in 1946. At first militant, it became subordinated to the management, as illustrated by the 1962 agreement with the management on collaboration, entitled 'Industrial Manifesto.' Similar agreements were signed in 1996 and 1998. Union leadership is recruited from higher-rank employees and active involvement in union's activities improves employees' chances for career advancement in the company (Kaneko, 2006: 199f.). In 1972, the Toyota trade union and the unions of Toyota's affiliated enterprises and sub-contractors joined together to form the Federation of All Toyota Workers' Unions (ATWU). In 2004, ATWU counted 108 manufacturers' unions and 180 dealers' unions, totaling 288 unions with 266,000 worker members (ibid: 201). The ATWU is part of the main Japanese trade union confederation, Rengo, which represents management-cooperative trade unions. In 1964, a cooperative leader mobilized several unions within Rengo and established the Japan Council of Metalworkers' Unions (IMF-JC) (Gordon, 1998). Rengo pursues conservative politics, concentrating on the interests of full-time employees, which sustains the dual labor market (Suzuki, 2010; Yun, 2010). The mainstream Japanese labor movement has so far abstained from confronting Japanese multinationals over their exploitative behavior (Williamson, 1994).

The Toyota company trade union refuses to criticize the company's conduct overseas, for example its links to Burmese military dictators through its joint venture with the Toyota Tsusho Corporation. Furthermore, the company relies on subcontracted and temporary workers, imports immigrant workers who work for half the minimum wage, introduces sweatshop working conditions, and undermines wages in the US car industry (National Labor Committee, 2008).

In this case study, I focus on the company's abuses in the Philippines, namely the repression of workers' freedom of association ${ }^{3}$ by refusing to recognize and certify the TMPCWA, which won legal recognition and the right to collective bargaining in March 2000. Since the beginning of the 1990s, repeated attempts have been made to organize unions in Toyota Philippines. ${ }^{4}$ The TMPCWA was established and registered with the government in 1998. In 2000, TMPCWA won the majority of employees' votes and should have received the certification needed to bargain with the management. However, the management did not accept this result and appealed to the authorities. In 2001, Toyota fired 233 workers, ${ }^{5}$ newly elected union officers, ${ }^{6}$ and supported the founding of a new company-friendly union. Since then, the TMPCWA has been in conflict with the company, demanding that the 2001 layoffs be reversed and that their union be recognized (Kaneko, 2006: $211 \mathrm{f})$.

The TMPCWA appealed to the International Labor Organization (ILO) Committee on Freedom of Association (CFA) stating that the government of the Philippines had been unfair to the workers and breached ILO Conventions 87 and 98 in February 2003. In November of the same year, the CFA ruled in favor of TMPCWA and issued a recommendation recognizing the violation of these conventions by the government of the Philippines. The ILO recommendation validated nearly all the union's claims regarding the three court cases against the company. The ILO ordered Toyota to begin collective bargaining negotiations and re-issued recommendations on this matter in 2004, 2005 and 2006 (Tono, 2006: 267). After falsifications in union elections in February 2006, the International Metalworkers' Federation (IMF) made an official decision in May to launch its own global campaign to demand that Toyota reinstate the dismissed workers (ibid: 269). Japanese officials have not yet taken any action. Toyota threatened President Arroyo that it would relocate the company because of the labor dispute, and Japanese enterprises in the Philippines mobilized around the issue. Since January 2008, a military station has been placed near the trade union office 
as a 'community service' (Tono, 2009). In August 2008, TMPCWA President Ed Cubelo received an assassination threat.

Although Japanese enterprise unions organize meetings with their counterparts in overseas subsidiaries, these meetings are more intended to foster employee identification with the company than to encourage international cooperation against it. Starting in 1973, meetings were held among Toyota trade unions as part of the IMF World Company Council (WCC) Programme. However, in 1984 the exchange program was suspended because the IMF complained that the meetings did not conform to their guidelines, for example, the Toyota trade union was excluding some partners, mainly more radical unions from the meetings and inviting managers to the meetings, both of which went against the IMF guidelines. In 1988, the ATWU started to invite Toyota's unions from other Asian countries to their meetings in order to encourage employees to identify with Toyota (Williamson, 1994). Toyota's main enterprise union is hostile to the TMCPWA. Japanese union representatives only visit and support Toyota Philippines' company union. The Japanese Toyota union has not responded to the Support Group's e-mail asking to join the Protest Toyota Campaign (interview Activist 1). The ATWU's attitude is typical of Japanese enterprise unions close to management. Trade unions in countries home to the headquarters of a multinational company tend to side with the management, which prevents international cooperation (Greer and Hauptmeier, 2008).

\section{The network of opposition in Japan and failed protests}

While the ATWU represents management-friendly unions, there are also oppositional leftwing minority unions (cp. Kawanishi, 1992) at Toyota. In the 1980s, an oppositional group (Sa'ha shosu-ha kumiai) was formed which consisted of left-wing activists who sought to influence the enterprise union's politics from within. As of 2006, the union consisted of 50 activists at Toyota in Toyota City, and has links to Zenroren and activists at Honda and Mitsubishi (Stewart, 2006: 760). On 22 January 2006, employees of Toyota Motor Corporation and Toyota affiliate companies namely DENSO, AISIN, and JTEKT - established another labor union, called All Toyota Labor Union (ATU). The union is open to all Toyota workers of, including part-time and foreign workers. According to the union, in November 2005 about 40 percent of the workforce had fixed-term contracts (Wakatsuki, 2006).

The Support Group for the TMPCWA, was formed in reaction to the dismissal of 227 union members at Toyota Philippines in March 2001. Immediately afterwards, in April 2001, the Asian Pacific Workers Solidarity Links Japan (APWSL Japan) invited the TMPCWA president Ed Cubelo to Japan to participate in an international symposium entitled 'The Auto Industry and Asian Workers.' The Japan Auto Workers Network (JAWN) attended the symposium and decided to take action. The Support Group's founding members were the All-Japan Shipbuilding and Engineering Union (Zenzousen) ${ }^{7}$ Kanto Regional Council, the minority union of Isuzu Motors which is an affiliate of the former union, the High School Teachers Union in Kanagawa Prefecture and the JAWN. The Support Group is a membership organization, mainly funded by membership fees. Most of the membership fees are donated to the TMPCWA. In 2010, the organization counted about 40 individual members. The affiliate unions were mainly located in Kanagawa Prefecture. The ATU, the independent union formed in 2006, joined the Support Group in Aichi Prefecture (interview Activist 1). Further groups involved in the campaign are AIROREN (Aichi Prefecture Federation of Trade Unions) Nagoya City, an independent and progressive trade union with links to subcontract and foreign guest workers employed in Aichi's auto industry; GU (General Union) Nagoya City, a 
union open to all workers; Nagoya City and JMIU Nagoya City, both independent grassroots unions open to all workers including subcontract, part-time and foreign workers (National Labor Committee 2008). This diverse network illustrates that the resistance involves both trade unions opposing the main company union as well as other social movement groups at company, local, and national level. A protest against the Toyota's Head Office was staged in Toyota City as a joint effort together with Zenzousen Kanto Regional Council.

The Support Group addressed Japanese judiciary institutions to defend Filipino workers, which is an innovative tactic for defending workers' rights in developing countries. In September 2004, the TMPCWA affiliated with Zenzousen Kanto Regional Council. As a result, in February 2005 the TMPCWA filed an unfair labor practice case with the Labor Relations Commission in Kanagawa Prefecture (Tono, 2006: 267). In December 2006, the Labor Relations Commission rejected the case. In response to this decision, the Support Group took the case to court but the rejection was not repealed (Activist 1). This tactic is an example of how labor activists may target a multinational in the country where its headquarters are based to enforce labor rights in developing countries (cp. Flynn and O’Brien, 2010). However, it has not yet produced any results.

Despite this rejection, the TMPCWA and the Support Group continued the campaign. The most recent protest and letter campaign was organized in September 2012 by the Support Group. One of the events was the General Protest Action staged on 19 September 2012 in front of the Toyota's Tokyo headquarters, in which various labor activists were mobilized by Zenzousen, a member of the Support Group. On 5 August 2013, the TMPCWA protested in front of the Philippines' Department of Labor and Employment, the Court of Appeals (to issue fair judgment against Toyota's 2010 illegal dismissal of the four union members), the Japanese Embassy in the Philippines, and Santa Rosa Toyota factory (TMCWA website, 5 August 2013).

On 28 May 2013, Toyota withdrew their lawsuits against the 20 TMPCWA leaders and members who had been sued by Toyota in the wake of the 2001 protest against mass dismissals. These lawsuits were based on the accusation that security guards suffered from 'grave coercion' as they were prevented from going into and out of the plant (TMPCWA, 28 May 2013). This retraction has been the only success of the campaign so far.

\section{The role of international exchange in establishing the Support Group}

Now I will turn to the origins of the campaign in Japan. In January 2000, the TMPCWA contacted activists in Japan through an international organization, the Young Christian Workers (YCW). Since the TMPCWA was established in 1998, it has been supported by the YCW. The YCW-Philippines addressed a request for support to Kojima Takeshi, Vice-Chairperson of the Yokosuka Union, a community union in Yokosuka City affiliated with the Zenzousen Kanto Regional Council. Kojima is Christian and has been a representative of a local solidarity group, the Yokosuka Citizen's Association in Solidarity with Filipino People, which was set up in 1983. He first collaborated with the YCW-Philippines during his study trips. Kojima discussed the call for support with a coordinator in JAWN, one of his long-term friends. This marked the beginning of JAWN and APWSL's involvement in combating abuses at Toyota Philippines (Tono, 2001). For the Japanese activists, their personal connection to members of the Filipino organization were the main motivation for them to get involved since they were then aware of the conditions at Toyota Philippines (interview Activist 1). This resembles the patterns present in North American anticorporate mobilization, in which bilateral relations and personal ties were decisive in organizing 
international protest (cp. Johnston and Laxer, 2003), whereas the Internet (cp. Clark and Themudo, 2006) was not important.

The Support Group example illustrates that Japanese social movements are inspired by international exchange, which results in the diffusion of ideas (cp. McAdam and Rucht, 1993). This example confirms that the assumption that idea spread from core to periphery is rightly criticized (cp. Chabot and Duyvendak, 2002). The global and semi-periphery (such as South Africa, Brazil, the Philippines, and South Korea) provide potential inspiration for the revitalization of labor movements in core countries (Moody, 1997; von Holdt, 2002; Waterman, 1993). Activists were motivated to form the Support Group thanks to the international experience of the APWSL Japan. The main trigger from abroad was the presence of activists in Asia: 'Suzuki Workers in India staged a strike and that has inspired us. We couldn't do much, but the fact that there was a strike in a Japanese-owned auto plant in Asia had a great impact on us.' (Activist 1). Examples of activism in the South have inspired Japanese activists (interview Zenrokyo), who realized that transnational mobilization in solidarity with the South is possible. However, the next section will demonstrate that there were already domestic organizational structures in place which served as a base for mobilization.

\section{The role of social movements' traditions in forming resistance}

Now I will turn to a further analysis of the local context that led to the Support Group's establishment. The support for the Filipino workers was preceded by the legacy of personal contacts among Japanese social movement groups and opening their agenda to international issues. The story of one of the Support Group's founders illustrates this development. He has been engaged in political activities since his high school years in the early 1970s and continued his political involvement at the auto plant where he started his career. He is a member of JAWN, which was formed in 1974 as a network of activists in the auto industry and later got involved with the APWSL. He also joined the Center for Transnational Labor Studies ${ }^{8}$ in the mid-nineties, where he learned a lot about labor movements abroad. He learned about the poor working conditions at Toyota by reading Kamata Satoshi's book 'Factory of Despair' published in 1972 (interview Activist $1)$.

The internationalist agenda within the labor movement was developed by the radical left movement in the 1960s and 1970s. After protesting the Vietnam War and the revision of the USJapan Security Treaty and being suppressed by the police, they decided to change their strategy. Its new aim was 'to return to the mass movement and to strengthen the militant labor movement at the shop-floor level' (Activist 3). Consequently, in 1977 a new labor journal called Rodo Joho (which means Labor Information) was created. It was a bimonthly labor journal, but also acted as a national network for militant labor, environmental and anti-discrimination movements. The Rodo Joho was one of the strongholds of workers opposed to Rengo's inception as a right-wing mobilization, and in response formed Zenrokyo in 1989 (Activist 3). Rodo Joho had a strong internationalist orientation, especially interested in solidarity with Chinese ${ }^{9}$ and Korean workers and the conduct of Japanese MNCs in Asia. Internationalism was the standpoint of the New Left, as opposed to the nationalistic tendencies of the Japan Communist Party (Activist 3).

The Asian Pacific Workers' Solidarity Links (APWSL) Japan Committee was formally established in 1990. In 2010, about 30 groups and 80 individuals were members of APWSL-Japan. Meetings are held on a monthly basis in the Tokyo and Osaka areas. It is part of an international network consisting of 16 national groups in the region. As a result, the international organization is 
subdivided into 4 regions. The regions (and countries) are as follows: South Asia (Bangladesh, India, Nepal, Pakistan, Sri Lanka), Southeast Asia (Indonesia, Malaysia, Philippines, Thailand), East Asia (Hong Kong, Japan, South Korea, Taiwan) and Oceania (Australia, Fiji, New Zealand) (organization's website). Japan's participation in the network was initiated by Rodo Joho's editor in chief as a workers' project that was part of the 1982 Asian Cultural Forum on Development. APWSL's first general meeting in Japan was held in 1989 as part of a major international forum called Peoples' Plan 21, which aimed to find an alternative system for the $21^{\text {st }}$ century, after the fall of communist regimes. There was a workers' workshop at People's Plan 21 and most of the participants were APWSL members. In 1999, unions and activists formed the APWSL Japan Committee, which provided Rodo Joho with an international perspective on labor struggle, thus acting as a sort of 'international section' of the journal (Activist 3).

As we have seen, the anti-globalization forces mobilizing in the 2000s stem from the traditions of both leftist movements and international exchange. The New Left movement of the 1960s and 1970s - originally concerned with the prevention of war - has re-oriented its cause towards economic globalization issues: 'In the sixties, we feared that Japan might re-militarize and invade Asian countries again. But in fact, Japan took a different course. Japan didn't invade directly, but supported the US invasion of Iraq and Afghanistan, while economically expanding to Asian countries. So we have to put up new forms of resistance to war and crimes committed by TNCs' (Activist 3). The Attac Japan was also established in the context of protests against the 2003 invasion of Iraq (Activist 2). Different types of movements, including the old labor movement, united to counter corporate globalization in Japan, a phenomenon that can also be observed in other regions (cp. Santos, 2008).

\section{Conclusions}

This paper has demonstrated the historic lack of success of the strategy of defending workers' rights in the Global South by targeting multinationals in the country in which their headquarters are based. More specifically, a foreign labor union that joined forces with Japanese labor unions to represent the interests of workers in the country where the headquarters of a multinational company are located met with no success, despite the innovative nature of this transnational tactic (cp. Flynn and O'Brien, 2010). This strategy's failure can be explained by two main contextual factors: the Japanese judiciary system's reticence to engage in trials against Japanese companies and the low mobilization potential for this cause on the part of the Japanese labor movement organizations that have a special relationship with the government and management. The Japanese judiciary system has not been a fruitful venue for defending Toyota Philippines workers' rights. The Kanagawa Labor Relations Commission rejected the case and the respective court supported this decision. It was difficult to gain any leverage in Japan because the main trade unions refused to cooperate to defend workers' rights at the Toyota subsidiary. However, the case revealed that the network of Japanese anti-corporate movements has some mobilization potential. Despite the fact that these organizations have few resources and members, they can achieve remarkable mobilization through cooperation. The mobilization against Toyota abuses resulted from cooperation at international, regional, national, local and company levels. The network is bound together by personal ties and membership overlaps. However, the protest was built in the context of the ideological divide within the Japanese labor movement. The network against corporate globalization unites radical trade unions and other social movements, which are interlinked at the local level and have transnational ties. 
This article has also explored the directions in which ideas and exchange flow. The Global South has an impact on the formulation of Japanese social movements' internationalist agenda. Filipino and Indian activists have inspired trade unions and labor activists to confront Japanese companies' abuses. This shows that the periphery can also shape the core, reinforcing the findings presented by Chabot and Duyvendak (2002).

So far, militant labor unions constitute a tiny faction of the Japanese labor movement in comparison with cooperative labor unions. The membership of the former amounts to approximately 40,000 union members out of 10 million total union members (Suzuki unpublished). Therefore, further research needs to focus on the processes that enable anti-corporate movements to influence mainstream trade unions. Labor movements in other regions and international trade union confederations (O'Brien, 2000) have experienced such shifts but in Japan, this prospect seems limited (Suzuki, 2008). Coalition building and the impact of other social movements on Rengo appears limited because Rengo does not perceive other movements as strong enough to be taken seriously (interview Rengo). While the response of the main Toyota union represents typical features of mainstream Japanese unions, one needs to consider exceptions to this general trend. Rengo has opened up membership to non-regular workers and some of its affiliates at the local level are responding to the structural changes in the labor market (Urano and Stewart, 2007; Urano and Stewart, 2009; Weathers, 2010). The Toyota case confirms that ideological divisions persist and prevent coalition building against corporate abuses. However, oppositional groups can exercise influence by applying pressure. Social movements' influence on Rengo can be observed, for example, in the Sumida case, a 1989 dispute between Korean workers and a Japanese company. At first reluctant to get involved, Rengo was pressured by People's Action Network to Monitor Japanese TNCs and media attention to take a stand (Williamson, 1994).

\section{ACKNOWLEDGMENTS AND FUNDING}

The research for this article was made possible thanks to the five-month JSPS Postdoctoral Fellowship for Foreign Researchers offered to me by the Japan Society for the Promotion of Science from December 2009 to May 2010. I would like to thank the Ohara Institute for Social Research at the Hosei University in Tokyo, and especially Professor Akira Suzuki for acting as my host. Professor Suzuki was extremely helpful in making my stay and research in Japan go smoothly. I appreciate his comments and our regular talks very much. Furthermore, research assistance by Seiichi Yamasaki was crucial for completing the article.

\section{APPENDIX: LIST OF INTERVIEWS}

Activist 1, the Support Group for the TMPCWA in Japan, Japan Auto Workers Network, Asia Pacific Workers Solidarity Links, 13 March 2010.

Activist 2, ATTAC Japan, Asia Pacific Workers Solidarity Links, 10 April 2010. 
Activist 3, Co-representative of Asia Pacific Workers Solidarity Links, Head of International Department in LaborNet Japan, member of Japan China Worker Exchange Society and of the Support Group for TMPCWA, 20 April 2010.

Activist 4, active in international affairs of Rengo, 11 May 2010.

Attac Japan, Secretary, 3 January 2010.

Rengo, Economic Department, 12 February 2010.

Rengo, Director of Department of International Affairs, 14 January 2010.

Zenrokyo, Secretary General, 27 January 2010.

Zenroren, Director of International Bureau, 27 January 2010.

\section{NOTES}

1. People's Action Network to Monitor Japanese TNCs (PAN) was established in 1987. The network consists of about 200 individual members. The stimuli to establish this organization was an appeal by a Korean trade union at the Japanese glove manufacturer, Asia Swany. The founder, Sakuma Shinichi and Wanatabe Tetsuro got involved in this issue because of their activities in the Japan-Korea Solidarity Movement supporting democratization in Korea. The First International Symposium on Monitoring Transnational Corporations (TNCs) in Asia was held in Tokyo on 7 December 1996. The meeting was attended by 100 people, including guests from South Korea and Hong Kong. The Symposium was sponsored by the People's Action Network to Monitor Japanese TNCs (PAN) and was supported by 12 civic groups, including APWSL Japan. Trade Union Council of Multinational Companies (TCM) and Rengo did not support the Symposium (Sakuma 1997).

2. The US government helped in establishing Sohyo because it wanted to strengthen the anticommunist forces. In 1954 and 1955, after Sohyo became too active, the US government prevented its development by helping in establishing the productivity movement. In the 1960s and 1970s, informal groups were converting workers towards cooperative ideology. Merit based wages, depicting all employees as equal, and quality circles - social movement created by management undermined the trade unions (Gordon 1998).

3. In the Philippines, the Constitution and the Labour Code guarantee the workers' rights to organise and to collective bargaining. The government has even ratified ILO Convention No. 87 on Freedom of Association and Protection of the Right to Organise and Convention No. 98 on the Right to Organise and Collective Bargaining. For the political and industrial relations context and foreign car makers in the Philippines, see Tono (2006). 
4. In 1988, Toyota started its operation in the Philippines. The first trade union called Toyota Motor Philippines Corporation Labour Union (TEMPCLU) was established in 1992 but it was pacified by a legal battle over recognition. In 1996, Ed Cubelo started to organize an underground trade union, which got support from the Young Christian Workers of the Philippines (YCW) (Tono 2006: 261f).

5. In April 1997, Toyota opened a second factory in Santa Rosa. Due to the economic crisis, the workforce was reduced by a top-up scheme on retirement allowance called the Voluntary Separation Program (VSP). The employment was reduced in the second half of the 1990s, having its peak amounting to 2,089 employees in 1996 to 1,242 employees in 2004 (Tono 2006: 253).

6. A list of union members' names and signatures, with more than 20 percent of all rank and file employees participating is required in order to register a trade union. Once it is registered, the union leaders' and members' names are publicly available (Tono 2006: 251).

7. This is a small, alternative industrial trade union. The majority of unionized workers in this sector are affiliated to the Japan Federation of Basic Industries Workers Union that consists of about 200,000 members and represents a management-oriented side and a conservative stance on environmental and military issues. All-Japan Shipbuilding and Engineering Union (Zenzousen) has been suppressed by management in the 1960s and nowadays consists of about 4000 members. The membership decline has been addressed by focusing on other industries and foreign trade unions (Professor Akira Suzuki, personal communication on 29 March 2010). All-Japan Shipbuilding and Engineering Union Kanto Regional Council is a member of IMF-JC (interview Activist 1).

8. The Center dissolved itself in 2008 and Labor Now is the succeeding organization.

9. Rodo Joho supported the Japan China Worker Exchange Society created in the early seventies. The Society sent the first delegation to China in 1985. Since then, the Society is sending a delegation to China every year and welcoming a delegation from China every two or three years. The

limitation of the Society is that it only has relations with the official union, All-China Federation of Trade Unions (Activist 3).

\section{REFERENCES}

Anner, M. (2003) 'Industrial Structure, the State, and Ideology: Shaping Labor Transnationalism in the Brazilian Auto Industry', Social Science History 27(4): 603-34.

Avenell, S.A. (2009) 'Civil Society and the New Civic Movements in Contemporary Japan: Convergence, Collaboration, and Transformation', Journal of Japanese Studies 35(2): 247283.

Beneria, L. (1995) 'Response: The Dynamics of Globalization', International Labor and Working Class History 47: 45-52. 
Benson, J. (1996) 'A Typology of Japanese Enterprise Unions', British Journal of Industrial Relations 34(3): 371-386.

Benson, J. and Zhu, Y. (2008) Trade Unions in Asia: an Economic and Sociological Analysis. London: Routledge.

Bronfenbrenner, K. (ed.) (2007) Global Unions. Challenging Transnational Capital through CrossBorder Campaigns. Ithaca and London: Cornell University Press.

Carlile, L.E. (1994) 'Party Politics and the Japanese Labor Movement: Rengo's New Political Force', Asian Survey 34(7): 606-620.

Chabot, S. and Duyvendak, J.W. (2002) 'Globalization and transnational diffusion between social movements: Reconceptualizing the dissemination of the Gandhian repertoire and the "coming out" routine', Theory and Society 31: 697-740.

Chan, J. (2008) Another Japan is Possible: New Social Movements and Global Citizenship Education. Stanford, CA: Stanford University Press.

Clark, J.D. and Themudo, N.S. (2006) 'Linking the Web and the Street: Internet-Based "Dotcauses" and the "Anti-Globalization" Movement', World Development 34(1): 50-74.

Crossley, N. (2002) 'Global anti-corporate struggle: a preliminary analysis', British Journal of Sociology 53(4): 667-691.

Crossley, N. (2003) 'Even Newer Social Movements? Anti-Corporate Protests, Capitalist Crises and the Remoralization of Society', Organization 10(2): 287-305.

Flynn, G. and O'Brien, R. (2010) 'An Internationalist Western Labour Response to the Globalization of India and China', Global Labour Journal 1(1): 178-202.

Funke, P.N. (2008) 'The World Social Forum: Social Forums as Resistance Relays', New Political Science 30(4): 449-474.

Gajewska, K. (2009) Transnational Labour Solidarity: Mechanisms of commitment to cooperation within the European trade union movement. London: Routledge.

Gajewska, K. (2013) 'Varieties of regional economic integration and labor internationalism: The case of Japanese trade unions in comparison', Economic and Industrial Democracy 34(2): 246267.

Gordon, A. (1998) The Wages of Affluence: Labor and Management in Postwar Japan. Cambridge, MA: Harvard University Press. 
Greer, I. and Hauptmeier, M. (2008) 'Political Entrepreneurs and Co-Managers: Labor Transnationalism at four Multinational Auto Companies', British Journal of Industrial Relations 46(1): 76-97.

Heckscher, C. and Carré, F. (2006) 'Strength in Networks: Employment Rights Organizations and the Problem of Co-Ordination', British Journal of Industrial Relations 44(4): 605-628.

Hirata, K. (2004) 'Civil Society and Japan's Dysfunctional Democracy', Journal of Developing Societies 20(1-2): 107-124.

Juravich, T. (2007) 'Beating Global Capital: A framework and Method for Union Strategic Corporate Research and Campaigns', in Bronfenbrenner, K. (ed.) Global Unions. Challenging Transnational Capital through Cross-Border Campaigns. Ithaca and London: Cornell University Press, pp. 16-39.

Jeong, D.Y. and Aguilera, R.V. (2008) 'The Evolution of Enterprise Unionism in Japan: A SocioPolitical Perspective', British Journal of Industrial Relations 46(1): 98-132.

Johnston, J. and Laxer, G. (2003) 'Solidarity in the age of globalization: Lessons from the anti-MAI and Zapatista struggles', Theory and Society 32: 39-91.

Juris, J.S. (2008) Networking Futures: The movements against corporate globalization. Durham and London: Duke University Press.

Kaneko, F. (2006) 'Toyota and Asian Automobile Workers', in: Chang, D. (ed.) Labour in Globalising Asian Corporations: A Portrait of Struggle. Hong Kong: Asia Monitor Resource Centre, pp. 181-214.

Kawanishi, H. (1992) Enterprise Unionism in Japan. London: Kegan Paul International.

Kwon, R., Reese, E., and Anantram, K. (2008) 'Core-Periphery Divisions among Labor Activists at the World Social Forum', Mobilization: An International Journal 13(4): 411-430.

Levesque, C. and Murray, G. (2002) 'Local versus Global: Activating Local Union Power in the Global Economy', Labor Studies Journal 27(3): 39-65.

McAdam, D. and Rucht, D. (1993) 'The cross-national diffusion of movement ideas', Annals of the American Academy of Political and Social Science 52 8: 56-87.

McDonald, K. (2002) 'From Solidarity to Fluidarity: social movements beyond 'collective identity' — the case of globalization conflicts', Social Movement Studies 1(2): 109-128.

Moody, K. (1997) Workers in a Lean World: Unions in the International Economy. London: Verso.

Munck, R. (2004) 'Globalization, Labor and the 'Polanyi Problem”, Labor History 45(3): 251-269. 
National Labor Committee (2008) The Toyota You Don't Know: The Race to the Bottom in the Auto Industry. Pittsburgh: National Labor Committee.

O'Brien, R. (2000) 'Workers and world order: the tentative transformation of the international union movement', Review of International Studies 26: 533-555.

Pekkanen, R. (2003) 'Molding Japanese Civil Society: State-Structured Incentives and the Patterning of Civil Society', in Schwartz, F.J. and Pharr, S.J. (eds.) The State of Civil Society in Japan. Cambridge. Cambridge, (UK): Cambridge University Press, pp. 116-134.

Ranald, P. (1999) 'Analysing, Organising, Resisting: Union Responses to the Asian Economic Crisis in East Asia, South Korea and the Philippines', The Journal of Industrial Relations 41(2): 295325.

Rehder, B. (2006) 'Legitimitätsdefizite des Co-Managements. Betriebliche Bündnisse für Arbeit als Konfliktfelder zwischen Arbeitsnehmer und betrieblicher Interessenvertretung', Zeitschrift für Soziologie 35(3): 227-42.

Sakuma, S. (1997) 'New Initiative to Monitor Asian TNCs Launched in Tokyo', APWSL Japan Newsletter 7(24), February.

Santos, B. de S. (2008) 'The World Social Forum and the Global Left', Politics and Society 36(2): 247-270.

Shimizu, H. et al (1998) 'Discussion: On the International Activities of Japanese Trade Unions', BULLETIN: Center for Transnational Labor Studies No. 4.

Steinhoff, P.G. (2008) 'Political Ties of Visible (Right) and Invisible (Left) Social Movements in Contemporary Japan', paper presented at Association for Asian Studies annual meeting. Atlanta, GA.

Stewart, P. (2006) 'Marginal movements and minority struggles? The case of the Japanese minority social and labour movements', The Sociology Review 54(4): 753-773.

Suzuki, A. (2003) 'The Death of Unions' Associational Life? Political and Cultural Aspects of Enterprise Unions', in Schwartz, F.J. and Pharr, S.J. (eds.) The State of Civil Society in Japan. Cambridge (UK): Cambridge University Press, pp. 195-213.

Suzuki, A. (2008) 'Community Unions in Japan: Similarities and Differences of Region-based Labour Movements between Japan and Other Industrialized Countries', Economic and Industrial Democracy 29(4): 492-520.

Suzuki, A. (unpublished) Labor Relations. Unpublished manuscript.

Suzuki, H. (2010) 'Employment Relations in Japan: Recent Changes under Global Competition and Recession', Journal of Industrial Relations 52(3): 387-401. 
Tackney, C.T. (2000) 'Changing Approaches to Employment Relations in Japan', in Bamber G.J., Park, F., Lee, C., Ross, P.K., and Broadbent, K. (eds.) Employment Relations in the Asia Pacific. Sydney: Allen \& Unwin, pp. 64-79.

Tackney, C.T. (2001) 'The Modes of Social Relation in Japanese Management Practice', in Cooper, C.L., Cartwright, S. and Earley, P.C. (eds.) The International Handbook of Organizational Culture and Climate. London: John Wiley \& Sons, pp. 377 - 390.

Tackney, C.T. (2002) 'Management Participation (Keiei Sanka) in Japan and the Asian Crisis', in Tomba, L. (ed.) East Asian Capitalism: Conflicts, Growth, and Crisis. Milano: Fondazione Giangiacomo Feltrinelli, pp. 347-732.

TMPCWA (2013) 'Philippine Toyota Union TMPCWA Succeeded in Getting 10-More-YearLong Criminal Case Eternally Dismissed', TMPCWA, 31 May 2013 [Online]. Available at http://www.tmpcwa.org/. [Accessed: 4 December 2013].

TMPCWA (2013) 'Action of TMPCWA', TMPCWA, 5 August 2013 [Online]. Available at http://www.tmpcwa.org/. [Accessed: 4 December 2013].

Tono, H. (2001) 'Solidarity with Philippine Toyota Workers - Globalization from Below: Protest Toyota Campaign Launched', APWSL Japan Newsletter No. 39, December.

Tono, H. (2006) 'Toyota in the Philippines: Drive Your Dreams or Drive to the Bottom?', in Chang, D. (ed.) Labour in Globalising Asian Corporations: A Portrait of Struggle. Hong Kong: Asia Monitor Resource Centre, pp. 247-271.

Tono, H. (2009) 'Doesn't Toyota lend ear for workers' voice? Interview with Ed Cubelo of TMPCWA'. Protest Toyota Campaign Newsletter No. 11, February 2009.

Urano, E.I. and Stewart, P. (2007) 'Including the Excluded Workers? The Challenges of Japan's Kanagawa City Union’, WorkingUSA: Journal of Labor and Society 10(March): 103-123.

Urano, E.I. and Stewart, P. (2009) 'Beyond Organised Labour in Japan - The Case of the Japanese Community Union Federation', in McBride, J. and Greenwood, I. (eds.) Community Unionism: A Comparative Analysis of Concepts and Contexts. Basingstoke: Palgrave MacMillan, pp. 121-138.

Von Holdt, K. (2002) 'Social movement unionism: the case of South Africa', Work, Employment and Society 16(2): 283-304.

Wad, P. and Tackney, C.T. (2009) 'Campaigning for Global Corporative Compliance with Core Labor Rights - The Case of Industrial Conflict at Toyota's Philippine Company', International Industrial Relations Research Association 15th World Congress, Sydney, August 24272009. 
Wakatsuki, T. (2006) 'A new, horizontal type of labor union emerged!' The Message of All Toyota Labor Union Presidents, 3 March 2006, [Online]. Available at http://www.labornet.org/ news/0306/horizu.htm. [Accessed: 20 January 2014].

Waterman, P. (1993) 'Social-movement unionism: A new union model for a new world order?' Review 16(3): 245-278.

Waterman, P. (1998) Globalization, Social Movements and the New Internationalisms. London: Mansel.

Weathers, C. (2010) 'The rising voice of Japan's community unions', in Vinken, H., Nishimura, Y., White, B.L.J. and Deguchi, M. (eds.) Civic Engagement in Contemporary Japan: Established and Emerging Repertoire. New York: Springer, pp. 67-83.

Williamson, H. (1994) Coping with the Miracle: Japan's Unions Explore New International Relations. London et al.: Pluto Press.

Yun, J.W. (2010) 'Unequal Japan: Conservative Corporatism and Labour Market Disparities', British Journal of Industrial Relations 48(1): 1-25.

\section{BIOGRAPHICAL NOTE}

KATARZYNA GAJEWSKA (PhD Bremen) is an independent scholar. She was awarded a Postdoctoral Fellowship from the Japan Society for the Promotion of Science from December 2009 to May 2010. She is the author of the book: Transnational Labour Solidarity: Mechanisms of Commitment to Cooperation within the European Trade Union Movement (Routledge 2009, soft cover 2013). Her articles have been or will be published in Comparative European Politics, European Journal of Industrial Relations, Economic and Industrial Democracy, Debatte, World Future Review and_Journal of Evolution and Technology. She co-authored articles in Industrial Relations Journal, Journal of Common Market Studies, and British Journal of Industrial Relations. Her non-academic articles appeared in Occupy.com and LeftEast. She currently does research on peer production of subsistence services. [email: K.Gajewska@gmx.net] 